\title{
Analisis Keterampilan Membaca Denah Di Kelas 3 Sekolah Dasar
}

\author{
Mutia Salsabila Wenno ${ }^{1 *}$, Dyah Lyesmaya ${ }^{2}$, Iis Nurasiah ${ }^{3}$ \\ ${ }^{1}$ Universitas Muhammadiyah Sukabumi, Sukabumi, Indonesia \\ 2 Universitas Muhammadiyah Sukabumi, Sukabumi, Indonesia \\ ${ }^{3}$ Universitas Muhammadiyah Sukabumi, Sukabumi, Indonesia \\ *Corresponding author: mutiasalsabilawenno.0499@gmail.com
}

\begin{abstract}
This study aims to describe the results of the analysis of floor plan reading skills in grade 3 elementary school. The research method used is descriptive qualitative method. Data collection techniques used are interviews, observation, and documentation. The author acts as a data collection instrument. The data analysis technique used consisted of data reduction (data reduction), data presentation (data display), and Conclusion Drawing/Verification. The research subjects used were grade 3 students in the 2020/2021 academic year. The number of students who were analyzed were 11 people. The results of the study revealed that the floor plan reading skills in grade 3 were based on the following floor plan reading indicators: 1) Analyzing the concept of floor plan reading with a percentage of $75 \%$ categorized as high. 2) Mention the cardinal directions on the plan with a percentage result of $51 \%$ categorized as low. 3) Perceiving the floor plan with a percentage result of $64 \%$ is categorized as low. 4) Determining the direction of the road on the floor plan with a percentage result of $51 \%$ categorized as low. and 5) Interpreting questions with a percentage result of $25 \%$ is categorized as very low. This is because the learning process is still teacher-centered, resulting in the low ability of students to read floor plans.
\end{abstract}

Keywords: floor plan reading skills; Indonesian language

\section{ABSTRAK}

Penelitian ini bertujuan untuk mendeskripsikan hasil analisis keterampilan membaca denah di kelas 3 Sekolah Dasar. Metode penelitian yang digunakan adalah metode kualitatif deskriptif. Teknik pengumpulan data yang digunakan adalah wawancara, observasi, dan dokumentasi. Penulis bertindak sebagai instrumen pengumpul data. Teknik analisis data yang digunakan terdiri dari reduksi data (data reduction), penyajian data (data display), dan Conclusion Drawing/Verification. Subjek penelitian yang digunakan adalah siswa kelas 3 tahun pelajaran 2020/2021. Jumlah siswa yang dianalisis sebanyak 11 orang. Hasil penelitian mengungkapkan bahwa keterampilan membaca denah di kelas 3 berdasarkan indikator membaca denah sebagai berikut 1) Menganalisis konsep membaca denah dengan hasil persentase $75 \%$ dikategorikan tinggi. 2) Menyebutkan arah mata angin pada denah dengan hasil persentase 51\% dikategorikan rendah. 3) Memersepsikan denah dengan hasil persentase $64 \%$ dikategorikan rendah. 4) Menentukan arah jalan pada denah dengan hasil persentase 51\% dikategorikan rendah. dan 5) Memaknai soal dengan hasil persentase 25\% dikategorikan sangat rendah. Hal tersebut dikarenakan proses pembelajaran masih berpusat pada guru sehingga mengakibatkan rendahnya kemampuan siswa dalam membaca denah.

Kata kunci: bahasa Indonesia; keterampilan membaca denah

\section{Pendahuluan}

Keterampilan bahasa memiliki empat keterampilan diantaranya keterampilan menulis, membaca, menyimak dan berbicara. Membaca merupakan salah satu dari empat keterampilan berbahasa yang mempunyai peranan penting dalam kehidupan berbahasa. Tarigan (2015:1) menyatakan bahwa keterampilan berbahasa dalam kurikulum di sekolah mencakup empat segi, yaitu (1)keterampilan menyimak/mendengarkan;(2) keterampilan berbicara; (3) keterampilan membaca; dan (4) keterampilan menulis. Kunci terpenting menuju keberhasilan siswa dalam menguasai keterampilan membaca yaitu pengembangan kosakata, kemampuan 
berbahasa lisan, kecintaan terhadap buku, dan aktivitas membaca. Membaca merupakan salah satu kemampuan yang harus dimiliki setiap siswa di samping keterampilan yang lain.

Keterampilan membaca adalah sesuatu hal yang penting, karena dengan membaca tidak hanya meningkatkan keterampilan dan menambah pengetahuan, tetapi dapat menggali lebih dalam lagi karena merupakan efek mendasar suatu perkembangan imajinasi (Budiarti \& Haryanto, 2016). Proses membaca sudah di ajarkan sejak kecil termasuk pada jenjang sekolah dasar, lembaga pendidikan harus mampu membuat peserta didik terbiasa dalam hal membaca seperti menurut (Rohim \& Rahmawati, 2020) sekolah merupakan suatu lembaga yang bertanggung jawab mewujudkan budaya baca yang merupakan bagian penting dalam kegiatan belajar. Oleh karena itu sekolah menerapkan gerakan literasi di setiap pembelajaran baik sebelum atau sesudah proses pembelajaran dilaksanakan.

Membaca adalah keterampilan kompleks yang melibatkan serangkaian keterampilan yang lebih kecil. Agar siswa dapat mencapai tingkat pemahaman tertentu, mereka harus menjalani proses yang cukup panjang. Febriyanto (2016) mengemukakan membaca yang perlu dijadikan perhatian adalah hal-hal penting berkenaan dengan informasi yang terdapat dalam bacaan yang dibacanya sebab tidak semua kata dalam bacaan merupakan hal penting yang harus diingat dan dipahami. Oleh karena itu, siswa perlu mengetahui dan menguasai beberapa aspek pemahaman membaca. Aspek dalam pemahaman bacaan meliputi (a) memahami makna sederhana (leksikal, tata bahasa, retoris), (b) memahami makna atau makna (maksud dan tujuan penulis, relevansi/keadaan budaya, reaksi pembaca), (c) evaluasi atau penilaian (isi) . , bentuk), (d) kecepatan membaca yang fleksibel, yang mudah disesuaikan dengan keadaan (Tarigan, 2015). Dalam pemahaman bacaan, siswa tidak hanya dituntut untuk memahami dan memahami isi bacaan, tetapi mereka juga harus mampu menganalisis atau mengevaluasi dan menghubungkannya dengan pengalaman dan pengetahuan awal mereka (Dalman, 2016).

Membaca memiliki kedudukan sebagai dasar untuk kemajuan dan keberhasilan dalam semua materi di sekolah, khususnya pada ranah sekolah dasar. Membaca merupakan keterampilan yang dimiliki setiap individu untuk memahami teks.Meskipun membaca berperan sebagai dasar untuk menguasai materi ajar, akan tetapi membaca merupakan salah satu isu pendidikan di Indonesia yang belum sepenuhnya terselesaikan (Rahman, dkk., 2018). Isu yang berkaitan dengan membaca yaitu rendahnya minat baca dan daya baca masyarakat di Indonesia, tidak terkecuali siswa sekolah dasar.

Hal ini dibuktikan berdasarkan survei Rahman, Wibawa, Nirmala, \& Sakti (2018) terhadap siswa SD yang mengemban Gerakan Literasi Sekolah di suatu kabupaten. Rahman, Wibawa, Nirmala, \& Sakti (2018) menemukan fakta bahwa kemampuan membaca siswa masih tergolong rendah, yang ditunjukkan dengan hasil tes kecepatan membaca. Idealnya siswa SD memiliki kecepatan membaca $150 \mathrm{kpm}$, namun nyatanya kecepatan membaca siswa hanya 104 $\mathrm{kpm}$. Kemudian, kemampuan siswa dalam menyelesaikan soal-soal pemahaman bacaan mencapai $45 \%$ dan termasuk dalam kategori rendah. Selanjutnya keterampilan literasi yang ditandai dengan kemampuan menyimak hasil membaca, menalar, dan menerjemahkan isi bacaan berada pada tingkat rendah yaitu $75 \%$ dengan tingkat pemahaman literasi pada tahap faktual literal. Hasil penelitian ini sejalan dengan pernyataan Humairoh \& Rahman (2016) yang menjelaskan bahwa rendahnya kemampuan pemahaman membaca siswa ditunjukkan 
dengan banyaknya siswa yang masih belum memahami isi bacaan yang dibacanya, dan siswa tidak dapat menemukan kalimat utama dalam bacaan.

Progress in International Reading Literacy Study (PIRLS) mengungkapkan hasil kajian tingkat literasi siswa SD di Indonesia tahun 2016 berada pada peringkat 41 dari 45 negara. Organization for Economic Cooperation and Development/ OECD dalam hal Programme for International Student Assessment (PISA) di tahun 2021 mengklaim siswa Indonesia berada pada tingkat ke 62 dengan skor 397 (skor rata-rata OECD 496) dengan jumlah peserta yaitu 70 Negara. Hal tersebut menunjukan rendahnya minat membaca siswa Indonesia.

Dalam masyarakat yang semakin kompleks seperti sekarang ini keterampilan bahasa sangat penting dan perlu dikuasai oleh siswa terutama keterampilan membaca. Pertama, saat siswa dalam proses penyelesaian studinya keterampilan membaca diperlukan dalam mempelajari setiap mata pelajaran. Kedua, siswa berada dalam kehidupan bermasyarakat di luar sekolah, keterampilan membaca masih juga diperlukan. Misalnya membaca koran, majalah, membaca menu di restoran, membaca teks film, dan sebagainya.

Berdasarkan hal di atas penulis memandang bahwa berbagai informasi yang berkembang di masyarakat menjadi tuntutan bagi guru untuk menyiapkan bacaan yang berisi informasi yang relevan untuk peserta didik. Selain itu perlu adanya pembiasaan dan pembelajaran yang ditanamkan oleh guru kepada peserta didik agar peserta didik terbiasa dan menyenangi kegiatan membaca. Untuk melatih dan menanamkan kebiasaan membaca tidaklah mudah, namun perlu adanya pembiasaan dan pembelajaran membaca sedini mungkin, terutama pada jenjang sekolah dasar.

Pada waktu ini pembelajaran dilaksanakan secara daring. Pelaksanaan pembelajaran secara daring ini membuat guru maupun siswa kesulitan dalam mengikuti dan menerima pembelajaran. Pembelajaran yang dilaksanakan di Sekolah Dasar dengan sistem daring, pada materi membaca denah guru dan siswa memanfaatkan grup WhatsApp untuk menerima materi yang diberikan oleh guru. Media yang digunakan oleh guru berupa gambar dan video pembelajaran. Maka pembelajaran daring merupakan suatu pembelajaran yang dilakukan secara online dengan jejaring web yang dilakukan oleh guru dan siswa.

Berdasarkan latar belakang masalah yang telah dipaparkan, penulis ingin mengetahui hasil keterampilan membaca denah siswa dalam pelajaran bahasa Indonesia yang dilaksanakan secara daring. Maka dari itu, penulis menyusun rumusan masalah Bagaimana hasil keterampilan membaca denah di kelas 3 sekolah dasar. Tujuan penelitian ini terfokus pada bagaimana hasil keterampilan membaca denah. Manfaat yang diharapkan dari penelitian ini adalah bagi siswa, siswa mendapatkan pengalaman belajar yang lebih berkesan dan menambah ilmu pengetahuan.

\section{Metode Penelitian}

Penelitian ini menggunakan jenis metode kualittaif deskriptif. Penulis mengolah mengolah data dan mengkaji permasalahan dalam bentuk deskripsi yaitu tidak dalam bentuk angka. Waktu yang digunakan peneliti untuk melaksanakan penelitian yaitu pada semester genap tahun 2020/2021. Penelitian dimulai ketika telah mendapatkan surat izin penelitian. Penulis melakukan penelitian di SDN 1 Cisande yang berada di Jalan Cikukulu Desa Cisande Kecamatan Cicantayan Kabupaten Sukabumi, Jawa Barat. Jumlah siswa kelas 3 sebanyak 39 
orang, subjek dalam penelitian ini adalah guru dan siswa dengan jumlah siswa 11 orang siswa dan 1 orang guru wali kelas 3. Peneliti tidak meneliti banyak subjek penelitian karena keterbatasan waktu dalam penelitian.

Penelitian ini menggunakan teknik pengumpulan data wawancara, observasi, dan dokumentasi yang berisi data hasil keterampilan membaca denah siswa kelas 3 SDN 1 Cisande. Tahap wawancara ini pihak yang diwawancarai mengenai kondisi siswa dalam pembelajaran. Wawancara dilakukan dengan sistem offline yang bertempat di SDN 1 Cisande dengan memperhatikan protokol kesehatan.

Dokumentasi pada penelitian ini penulis meminta data hasil tes tentang pembelajaran membaca denah siswa kelas 3 SDN 1 Cisande dalam bentuk foto. Penulis akan menganalisis bagaimana hasil nilai yang didapatkan setiap siswa di kelas 3 SDN 1 Cisande.

Teknik analisis data yang digunakan pada penelitian ini terdiri dari reduksi data (data reduction), penyajian data (data display), dan Conclusion Drawing/Verification. Oleh karena itu, penulis merangkum data yang didapatkan ketika wawancara, observasi dan dokumentasi yaitu memfokuskan hal yang penting berdasarkan keterampilan membaca denah siswa. Penyajian data dapat memudahkan penulis untuk memahami apa yang terjadi dengan disajikan dalam bentuk uraian. Tahapan conclusion Drawing/Verification, data yang telah diperoleh setelah dilakukan tahapan reduksi data dengan penyajian data, kemudian data tersebut disimpulkan.

\section{Hasil dan Pembahasan}

Hasil wawancara bahwa metode yang digunakan adalah metode tanya jawab dan ceramah. Sumber buku yang digunakan oleh guru kelas 3 yaitu buku paket tematik seperti buku guru dan buku siswa. Guru menganggap materi denah merupakan materi yang harus siswa pahami dan hafal agar siswa dapat mengaplikasikannya dalam kehidupan sehari-hari. Sebagaimana yang diketahui terdapat 5 indikator penelitian yang dikemukaan. Diantara indikator penelitian ini adalah

Indikator pertama adalah menganalisis konsep membaca denah, masih ada sebagian siswa yang kurang tepat dalam menjawab, tetapi permasalahan siswa yang kurang tepat dalam menjawab dapat diperbaiki seperti menurut (Munawir, 2020). Pada indikator menganalisis konsep membaca denah, hasil siswa dipersentasekan sebanyak $76 \%$ dalam kategori baik, namun masih tetap membutuhkan bimbingan guru.

Indikator kedua adalah menyebutkan arah mata angin pada denah, terlihat dari proses pembelajaran tidak adanya siswa dalam menyebutkan arah mata angin saat proses pembelajaran sedang berlangsung. Karena guru tidak memberikan arahan untuk siswanya membaca denah saat proses pembelajaran melalui whatsApp grup sehingga siswa tidak menyebutkan arah mata angin pada denah. Kemampuan ini mengarahkan siswa untuk menyebutkan arah mata angin pada denah. Pada indikator menyebutkan arah mata angin pada denah siswa mendapatkan hasil persentase $51 \%$ dengan kategori rendah. Sehingga dapat disimpulkan bahwa kebanyakan siswa belum mampu menguasai indikator tersebut.

Indikator ketiga adalah memersepsikan denah, tidak semua siswa menganggapi soal denah pada saat proses pembelajaran karena guru tidak memberikan contoh denah seperti apa hanya saja guru memberikan arahan untuk membuka buku paket tematik tetapi tidak ada tindak lanjut lagi setelah guru memerintahkan siswa untuk membaca buku paket tematik. 
Kemampuan ini tidak semua siswa menganggapi materi denah pada saat proses pembelajaran. Pada indikator memersepsikan denah siswa mendapatkan hasil persentase $64 \%$ dengan kategori rendah. Sehingga dapat disimpulkan bahwa kebanyakan siswa belum mampu menguasai indikator tersebut.

Indikator keempat adalah menentukan arah jalan pada denah, kondisi siswa saat proses pembelajaran tidak ada yang dapat menentukan arah jalan pada denah selain tidak ada pembahasan anatra guru dan siswa mengenai menunjukannya arah jalan pada denah, hanya saja guru memberikan penugasan untuk membuatkan denah rumah masing-masing beserta dibacakan arah jalan denah rumah masing-masingnya. Tidak semua siswa menjawab atau membacakannya dengan benar, kebanyakan siswa keliru membacakanya dengan arah mata angin. Sehingga siswa salah menyebutkan posisi letak denah rumah siswa tersebut. Sebagian siswa tidak bisa menentukan arah jalan pada denah karena kesalahan menentukan arah jalan seperti . Pada indikator menentukan arah jalan denah mendapatkan hasil persentase 51\% dengan kategori rendah. Sehingga dapat disimpulkan bahwa kebanyakan siswa belum mampu menguasai indikator tersebut.

Indikator kelima adalah memaknai soal, masih banyak siswa yang belum paham dengan konsep arah mata angin dalam membaca denah. Diketahui saat siswa menyelesaikan soal tentang membaca denah. Hasil yang diperoleh siswa beragam seperti ada yang menuliskannya dengan lengkap dan adapun secara garis besarnya saja. Terdapat 3 orang siswa yang menuliskannya dengan sangat lengkap, 4 orang yang menuliskan dengan kurang lengkap, dan 3 orang yang menuliskan dengan sangat kurang lengkap. Kemampuan ini hampir semua siswa tidak paham saat memaknai soal pada saat proses pembelajaran. Pada indikator memersepsikan denah siswa mendapatkan hasil persentase $25 \%$ dengan kategori sangat rendah. Sehingga dapat disimpulkan bahwa hampir semua siswa belum mampu menguasai indikator tersebut.

Berdasarkan fenomena di atas, bimbingan orang tua serta bimbingan guru sangat dibutuhkan agar siswa yang belum berkategori baik dalam membaca denah dapat menangkap konsep pembacaan denah dengan lebih baik. Selain itu, Pemberian arahan didalam proses pembelajaran denah sangat diperlukan agar siswa dapat memahami konsep, dapat menangkap apa yang ingin di ajarkan oleh pendidik serta pencapaian kompetensi akamedik oleh siswa dapat tercapai.

Pemahaman siswa kelas 3 terhadap materi ini dapat di lihat dari hasil ulangan harian dan hasil ulangan akhir semester. Jumlah siswa kelas 3 berjumlah 39 orang dan Kriteria Ketuntasan Minimal (KKM) mata pelajaran bahasa Indonesia yang telah ditentukan oleh sekolah yaitu 70. Peneliti memperoleh data dari 11 orang siswa yang terdiri dari 3 orang yang memiliki nilai sangat baik 4 orang memiliki nilai baik dan 4 orang memiliki nilai kurang baik, masing-masing terdiri dari laki-laki dan perempuan. Berikut kategori nilai keterampilan membaca denah : 
Tabel 1. Kategori Nilai Keterampilan Membaca Denah

\begin{tabular}{cc}
\hline Kategori & Jumlah \\
\hline Nilai Tertinggi & 95 \\
Nilai Terendah & 55 \\
Rata-rata & 75,5 \\
$>$ KKM $(70)$ & $70 \%$ \\
$<$ KKM $(70)$ & $40 \%$ \\
\hline
\end{tabular}

Berdasarkan tabel diatas dapat diketahui bahwa nilai 95 berada di posisi nilai tertinggi, nilai 55 adalah nilai terendah yang diperoleh sisa, dan rata-rata siswa berada di angkat 75,5. Adapun nilai KKM lebih besar dari 70 diperoleh dengan perentase 70\% dan nilai KKM lebih kecil dari 70 diperoleh dengan perentase $40 \%$.

\section{Kesimpulan}

Berdasarkan hasil penelitian yang telah didapatkan keterampilan membaca denah siswa kelas 3 SDN 1 Cisande bahwa indikator pertama dapat dikategorikan tinggi, indikator kedua dikategorikan rendah, indikator ke-3 dapat dikategorikan rendah, indikator ke-4 dikategorikan rendah, dan indikator ke-5 dapat dikatakan sangat rendah. Hal tersebut terbukti berdasarkan data nilai yang menunjukkan dari 11 sampel siswa masih banyak yang belum menguasai ke-5 indikator keterampilan membaca denah. Oleh karena itu, dapat di simpulkan bahwa keterampilan membaca denah dapat di kategorikan sangat rendah pada indikator ke5. Berdasarkan hasil penelitian yang didapatkan, penulis memberikan beberapa saran yaitu guru harus lebih memperhatikan metode pembelajaran meskipun pembelajaran dilakukan secara daring. Pembelajaran yang dilaksanakan secara tidak langsung sebaiknya guru menggunakan aplikasi agar bisa langsung bertatap muka dengan siswa seperti melakukan video call, atau aplikasi lain. Sehingga bisa menumbuhkan minat siswa dalam pembelajaran. Ketika siswa belum memahami materi siswa dapat bertanya langsung dan mendapat jawaban dari pertanyaan yang belum dikuasai.

\section{Daftar Pustaka}

Budiarti, W. N., \& Haryanto, H. (2016). Pengembangan Media Komik Untuk Meningkatkan Motivasi Belajar Dan Keterampilan Membaca Pemahaman Siswa Kelas Iv. Jurnal Prima Edukasia, 4(2), 233. https://doi.org/10.21831/jpe.v4i2.6295

Daulay, M. I. (2021). Pengembangan Media Komik untuk Meningkatkan Keterampilan Membaca Pemahaman Siswa Kelas IV SDN 41 Pekanbaru. Jurnal Onoma: Pendidikan, Bahasa, Dan Sastra, 7(1), 24-34.

Dwiarno, P. A. (2017). Peningkatan Keterampilan Membaca Pemahaman pada Siswa Kelas III SDN Sumberbening 4 Kecamatan Bringin Kabupaten Ngawi Melalui Teknik CIRC. Jurnal Pendidikan Modern, 3(1), 42-53.

Farhurohman, O. (2017). Implementasi Pembelajaran Bahasa Indonesia di SD/MI. Primary: Jurnal Keilmuan dan Kependidikan Dasar, 9(1), 23-34. 
Febriyanto, B. (2016). Penerapan Model Cooperative Integrated Reading and Composition Dalam Pembelajaran Keterampilan Membaca Pemahaman. Jurnal Cakrawala Pendas, 2(2). https://doi.org/10.31949/jcp.v2i2.763

Irawan, D. (2021). PENDEKATAN PEMBELAJARAN MEMBACA PADA BUKU TEKS PELAJARAN TEMATIK KELAS III SD/MI DI KECAMATAN PURBALINGGA. Khazanah Pendidikan, 15(2), 173-180.

Harahap, M. H., Faisal, F., Hasibuan, N. I., Nugrahaningsih, R. H. D., \& Azis, A. C. K. (2017). Pengembangan Program Literasi Sekolah Untuk Meningkatkan Kualitas Pendidikan Dasar Tingkat Sekolah Menengah Pertama Negeri Di Kota Medan. Jurnal Pembangunan Perkotaan, 5(2), 115-128.

Hasnan, A. D., Fauziah, A. N., Ramadhania, A. D., Lahfah, S., \& Sembiring, J. T. (2020). MENINGKATKAN KEMAMPUAN MEMBACA PEMAHAMAN MELALUI CERITA FABEL DAN CERITA SERIAL DI KELAS 2B SDN KARAWANG WETAN III (Studi Deskriptif dan Analisis di Kelas 2B SDN Karawang Wetan III). PROCEEDINGS UNIVERSITAS PAMULANG, 1(2).

Humairoh, S., \& Rahman. (2016). Pengaruh Model Cooperative Integrated Reading and Composition (CIRC) dan Cooperative Script (CS) terhadap Kemampuan Membaca Pemahaman Siswa Sekolah Dasar. Metodik Didaktik, 11 (1), 8-20.

Lumbarina, L. (2018). Peningkatan Kemampuan Bahasa Indonesia Mendeskripsikan Tempat Sesuai Denah melalui Metode Kerja Kelompok Siswa Kelas IV SD Negeri 011 Pulau Kedundung. Geram, 6(2), 35-43. https://doi.org/10.25299/geram.2018.vol6(2).2055

Marsino, M. Peningkatan Kemampuan Mendeskripsikan Petunjuk Denah melalui Metode Demonstrasi Siswa Kelas Ivsdn 006 Pagaran Tapah Darussalam. Primary, 5(3), 26-33.

Munawir, A. (2020). Penguasaan Konsep Arah Mata Angin dengan Metode Treasure Hunt di Sekolah Dasar. Didaktika: Jurnal Kependidikan, 9(2), 265-272. https://jurnaldidaktika.org/contents/article/view/36.

Nurvitriawati, N., \& Sulfasyah, S. (2018). Pengaruh Model Explicit Instruction terhadap Hasil Belajar Bahasa Indonesia Membaca Konsep Denah Pada Murid Kelas IV SD. JKPD (Jurnal Kajian Pendidikan Dasar), 3(1), 417-428.

Perkasa, A. (2018). Analisis kesalahan siswa dalam menyelesaikan soal tentang membaca denah. Jurnal Kiprah, 6(2), 48-53.

Rohim, D. C., \& Rahmawati, S. (2020). Peran Literasi dalam Meningkatkan Minat Baca Siswa di Sekolah Dasar. Jurnal Review Pendidikan Dasar: Jurnal Kajian Pendidikan Dan Hasil Penelitian, 6(3). https://journal.unesa.ac.id/index.php/PD/article/view/10412/4379

Rudi, A., \& Seran, E. Y. KEMAMPUAN MEMAHAMI DENAH SISWA SEKOLAH DASAR DENGAN PENDEKATAN LINGKUNGAN ALAM SEKITAR (PLAS). Jurnal Educhild: Pendidikan dan Sosial, 8(1), 7-11.

Rahman, dkk. (2018). Pop-Up Book in Reading Comprehension Ability Context in Thematic Learning. Yogyakarta: Universitas Negeri Yogyakarta. 
Tamad, T. (2019). PENINGKATAN KEMAMPUAN MEMBACA PETUNJUK DENAH/PETA DENGAN ALAT PERAGA DENAH LOKASI (DELOK) DAN METODE SALING SILANG HASIL KELOMPOK (SSHK). JURNAL KONFIKS, 6(1), 1-7.

Ulfana, L., \& MARET, U. S. (2017). PENINGKATAN KETERAMPILAN MEMBACA AKSARA JAWA MELALUI MODEL PEMBELAJARAN KOOPERATIF TIPE THINK PAIR SHARE DENGAN MEDIA FLASHCARD. Didaktika Dwija Indria, 5(6). 